\title{
Article \\ Cytogenetic, Serum Liver Enzymes and Liver Cell Pathology of the Hampala Barb Fish (Hampala macrolepidota) Affected by Toxic Elements in the Contaminated Nam Kok River near the Sepon Gold-Copper Mine, Lao PDR
}

\author{
Latsamy Soulivongsa ${ }^{1,2}$, Bundit Tengjaroenkul ${ }^{1,2}$, Isara Patawang ${ }^{3}$ and Lamyai Neeratanaphan ${ }^{4, *}$ \\ 1 Toxic Substances, Microorganisms and Feed Additives in Livestock and Aquatic Animals for Food Safety \\ Research Program, Khon Kaen University, Khon Kaen 40002, Thailand; soulivongmee@gmail.com (L.S.); \\ btengjar@kku.ac.th (B.T.) \\ 2 Division of Livestock Medicine, Faculty of Veterinary Medicine, Khon Kaen University, \\ Khon Kaen 40002, Thailand \\ 3 Research Center in Bioresources for Agriculture, Industry and Medicine, Chiang Mai University, \\ Chiang Mai 50200, Thailand; isara.p@cmu.ac.th \\ 4 Division of Environmental Science, Faculty of Science, Khon Kaen University, Khon Kaen 40002, Thailand \\ * Correspondence: hlamya@kku.ac.th
}

Citation: Soulivongsa, L;

Tengjaroenkul, B.; Patawang, I.;

Neeratanaphan, L. Cytogenetic, Serum Liver Enzymes and Liver Cell Pathology of the Hampala Barb Fish (Hampala macrolepidota) Affected by

Toxic Elements in the Contaminated Nam Kok River near the Sepon GoldCopper Mine, Lao PDR. Int. J. Environ. Res. Public Health 2021, 18 , 5854. https://doi.org/10.3390/ ijerph18115854

Academic Editor: Guillermo Blanco

Received: 2 April 2021

Accepted: 28 May 2021

Published: 29 May 2021

Publisher's Note: MDPI stays neutral with regard to jurisdictional claims in published maps and institutional affiliations.

Copyright: () 2021 by the authors. Licensee MDPI, Basel, Switzerland. This article is an open access article distributed under the terms and conditions of the Creative Commons Attribution (CC BY) license (https:// creativecommons.org/licenses/by/ $4.0 /)$.

\begin{abstract}
This study aimed to determine toxic element concentrations in aquatic environments, including water and sediment, and in the Hampala macrolepidota fish, and to evaluate chromosome abnormalities, serum liver enzyme changes and liver histopathological alterations in $H$. macrolepidota from the Nam Kok River near the Sepon gold-copper mine, Lao People's Democratic Republic, as compared with a control area without mining activity. The results revealed significant differences $(p<0.05)$ in $\mathrm{As}, \mathrm{Ba}, \mathrm{Cu}, \mathrm{Fe}, \mathrm{Mn}, \mathrm{Ni}$, Se and $\mathrm{Zn}$ in water, in all of the studied potentially toxic elements in sediment, and in $\mathrm{As}, \mathrm{Ba}, \mathrm{Cd}, \mathrm{Cr}, \mathrm{Cu}, \mathrm{Mn}, \mathrm{Ni}$, Se, and $\mathrm{Zn}$ in the fish between the study and control areas. A chromosome assessment demonstrated 6 types of chromosome abnormalities, among which centric gap had the highest total number of chromosome abnormalities. Percentage of chromosome abnormalities, percentage of cells with chromosome abnormalities and serum liver enzymes in $H$. macrolepidota were significantly different $(p<0.05)$ between the two studied areas and were higher in the contaminated fish than in the control fish. The observation of liver histopathological changes revealed cellular degeneration, such as nuclear damage, abnormal cytoplasmic mitochondria and the disintegration of rough endoplasmic reticulum. The results indicate that the contamination of potentially toxic elements in the Nam Kok River near the Sepon gold-copper mine area negatively affected chromosomes, serum liver enzymes and liver cell structures in H. macrolepidota.
\end{abstract}

Keywords: chromosome; environment; fish; lesion; metal; toxicity

\section{Introduction}

The Lao People's Democratic Republic includes mountainous regions with natural scenery as well as various valuable mineral resources in several regions of the country. To date, the Lao government has promoted ore resources as a mechanism for increasing the gross domestic product of the country [1,2]. In 2018, the major valuable ore commodities from the Lao People's Democratic Republic were gold and copper, with estimated export values of 200 and 502 million USD, respectively [3,4]. By 2020, the value of the total metal exports is predicted to account for $10 \%$ of Laos's gross domestic product. The Sepon gold-copper mine in the Savannakhet Province is the second largest gold-copper mine, which contributes to $90 \%$ of the country's total economic value from the mining sector $[1,3]$. In addition to the mining industry, aquaculture and fishery are major essential economic sectors in the Lao People's Democratic Republic, accounting for more than half of animal 
protein sources [5]. However, at present the volume of fish captured from streams, rivers and reservoirs in Lao PDR is decreasing due to the low surface water qualities, which is similar to other polluted areas [6,7]. Previous reports have mentioned that potentially toxic elements can negatively affect the structure and metabolism of animal and human cells, tissues, and organs, can cause chromosome and DNA damage, tumors, and can drive evolution [8-10].

Hampala macrolepidota is a carnivorous fish species with a high demand for human consumption in Laos and other countries in Southeast Asia [11]. Fish are generally accepted as the main depots of potentially toxic elements in ecosystems, and they are selected as appropriate biomonitors for the assessment of potentially toxic element contamination in aqueous environments [12-14]. As a result, the rapid growth of gold-copper mining in the Lao People's Democratic Republic has raised intense concerns involving potentially toxic element emissions into aquatic ecosystems; however, data involving types and concentrations of potentially toxic elements in the environment and the health effects of these elements on H. macrolepidota are limited. Only Soulivongsa et al. [15] has reported on five toxic elements in the Nam Kok River and aquatic organisms. Fe, Mn and Ni in the river water as well as As and $\mathrm{Cd}$ in the sediment and $\mathrm{As}$ and $\mathrm{Cd}$ in Osterochilus vittatus fish samples in the river exceeded standard values. Therefore, studies on the concentrations of potentially toxic elements, including $\mathrm{As}, \mathrm{Cd}, \mathrm{Pb}, \mathrm{Cr}, \mathrm{Ba}, \mathrm{Cu}, \mathrm{Fe}, \mathrm{Mn}, \mathrm{Ni}, \mathrm{Se}$, and $\mathrm{Zn}$ in water, sediment and H. macrolepidota, as well as their potential toxic effects on chromosomes, serum liver enzyme indices and the liver cell pathology of H. macrolepidota in the Nam Kok River were conducted. Information on the potentially toxic elements impacting several aspects of this carnivorous fish species can be applied for environmental and human health risk management as well as for setting regulations, laws and policies for the mining industry in the Lao People's Democratic Republic.

\section{Materials and Methods}

\subsection{Study Area}

The Nam Kok River, located near a Sepon gold-copper mine in the Viraboury District, Savannakhet Province, Lao People's Democratic Republic, at GPS location $16^{\circ} 52^{\prime} 06.32^{\prime \prime} \mathrm{N}$ $106^{\circ} 02^{\prime} 22.88^{\prime \prime}$ E, was set as the study area, and the Nam Souang River in the Naxaythong District, Vientiane, at GPS location $18^{\circ} 14^{\prime} 52.88^{\prime \prime} \mathrm{N} 102^{\circ} 27^{\prime} 54.78^{\prime \prime} \mathrm{E}$, near agricultural and domestic areas without mining and electronic activities, i.e., potential load for naturally leached elements, was set as a control area (Figure 1).

\subsection{Water Quality Parameters}

The water quality parameters, including dissolved oxygen (DO), hydrogen potential $(\mathrm{pH})$, temperature, total hardness $(\mathrm{TH})$, carbonate hardness $(\mathrm{CH})$ and electrical conductivity (EC), were determined at the experimental areas using electrical detectors at 8:00 a.m., whereas nitrite, nitrate and ammonia were determined using standard titration methods (Table 1).

Table 1. Analytical methods used for measurements of water quality parameters.

\begin{tabular}{cc}
\hline Water Quality Parameters & Analytical Methods \\
\hline Dissolved oxygen & DO meter, Model 966, Mettler Toledo \\
Temperature & pH meter, Model EcoScan pH 5 \\
Total hardness, Carbonate hardness & Eutech Thermometer \\
Electrical conductivity & Test kits, Chulalongkorn University, Thailand \\
Nitrite, Nitrate, Ammonia & EC meter, Mettler Toledo \\
\hline
\end{tabular}




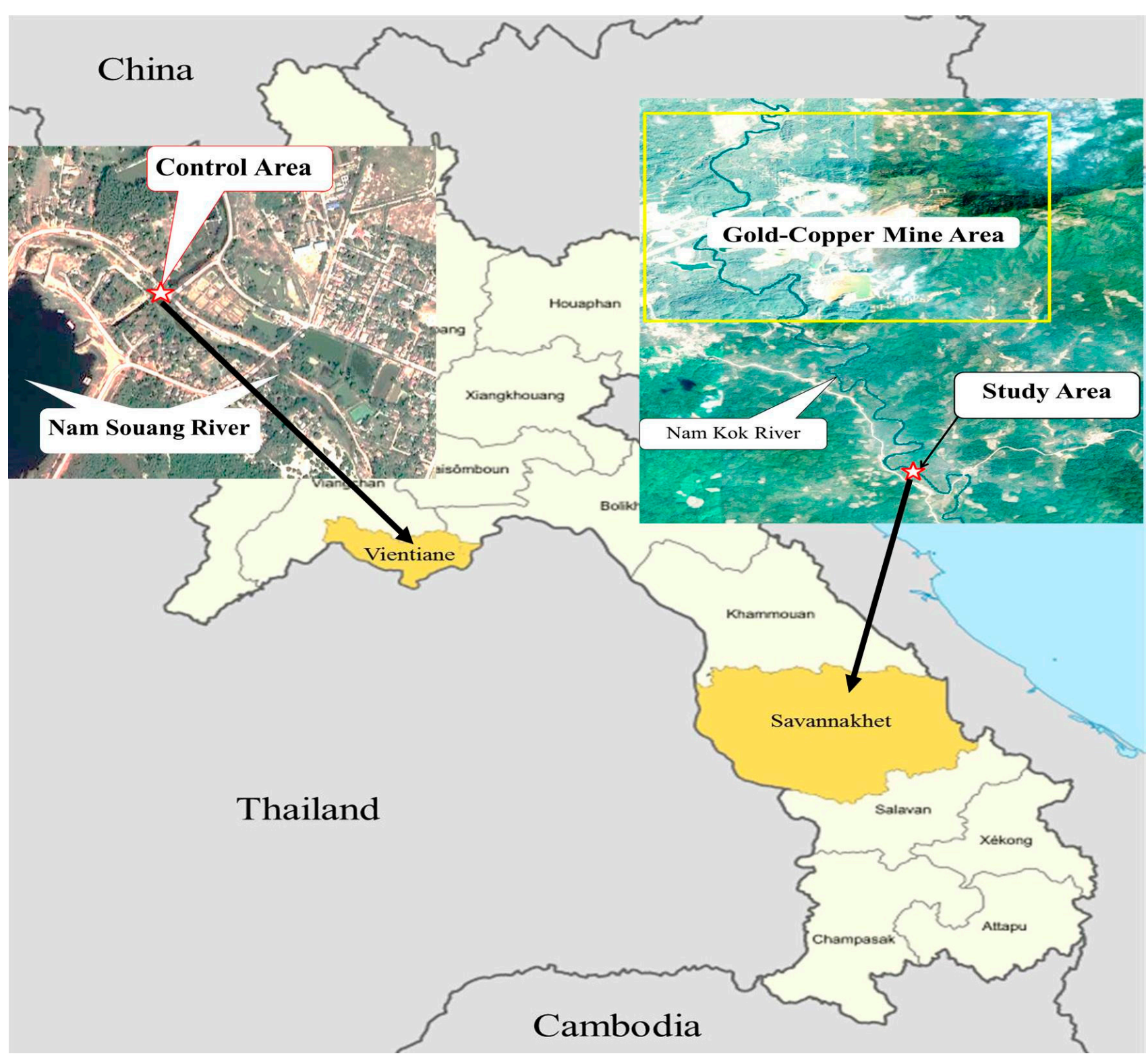

Figure 1. Geographical locations of the Nam Souang River as the control area (left) and the Nam Kok River near the Sepon gold-copper mine as the study area (right).

\subsection{Sample Collection}

Water, sediment, and H. macrolepidota fish samples were randomly collected in three replicates $(n=9)$ from the Nam Kok River near the Sepon gold-copper mine (as the study area) and the Nam Souang River (as the control area) during October-December 2019 (Figure 1). In order to avoid resuspension concern, the water samples were collected at a depth of $30 \mathrm{~cm}$ from the surface before sediment collection. Nitric acid was then added to the water samples, and the sediment samples were air dried before quantification of potentially toxic element concentrations. Ten $H$. macrolepidota samples were measured for potentially toxic element contents in the fish muscles as a result of biomagnification in the food chain due to the risks to human health, including chromosome abnormalities from kidney cells, serum liver enzymes and liver histopathological changes. The average body weights of $H$. macrolepidota taken from the Nam Kok and Nam Souang Rivers were not significantly different $(p>0.05)$, at approximately $103.00 \pm 13.82 \mathrm{~g}$ and $97.20 \pm 9.08 \mathrm{~g}$, respectively. 


\subsection{Measurements of the Potentially Toxic Element Concentrations \\ 2.4.1. Water Samples}

A total of $25 \mathrm{~mL}$ of each water sample was mixed with $1.25 \mathrm{~mL}$ of $30 \% \mathrm{HNO}_{3}$ (ACS grade), then the sample was digested on a hot plate at $95 \pm 5{ }^{\circ} \mathrm{C}$ for $60 \mathrm{~min}$. After cooling, the digested sample was adjusted to $25 \mathrm{~mL}$ with deionized water and filtered through cellulose paper No. 1 . The final sample was analyzed via inductively coupled plasma optical emission spectrometry (ICP-OES) [16].

\subsubsection{Sediment Samples}

Each sediment sample with an exact weight of $1.0 \mathrm{~g}$ (Mettler Toledo, Model MS 105, Greifensee, Switzerland) was sequentially digested with $5 \mathrm{~mL}$ of nitric acid (ACS grade), $15 \mathrm{~mL}$ of hydrochloric acid (ACS grade) and $10 \mathrm{~mL}$ of hydrogen peroxide (ACS grade) in a heating mantle at $95 \pm 5^{\circ} \mathrm{C}$ for $2 \mathrm{~h}$. After cooling, the sample was adjusted to a volume of $50 \mathrm{~mL}$ with deionized water and filtered through cellulose filter paper No. 42. The final samples were then analyzed via ICP-OES (PerkinElmer, Inc., Model optima 8300, Waltham, MA, USA) [17].

\subsubsection{Fish Samples}

Each fish muscle sample with an exact weight of $1.0 \mathrm{~g}$ was mixed with sulfuric and nitric acid (ACS grade) and digested on a hot plate at $60{ }^{\circ} \mathrm{C}$ for $30 \mathrm{~min}$. Then, $10 \mathrm{~mL}$ of hydrogen peroxide (ACS grade) was mixed and digested on a hot plate for $1 \mathrm{~h}$. After cooling, the digested sample was adjusted to a volume of $25 \mathrm{~mL}$ with deionized water. Then the mixture was passed through filtered paper No. 1. Finally, the sample was analyzed via ICP-OES (PerkinElmer, Inc., Model optima 8300, Waltham, MA, USA) [16].

\subsubsection{Quality Control and Quality Assurance}

The ICP-OES wavelengths for the analysis of $\mathrm{As}, \mathrm{Ba}, \mathrm{Cd}, \mathrm{Cr}, \mathrm{Cu}, \mathrm{Fe}, \mathrm{Mn}, \mathrm{Ni}, \mathrm{Pb}$, Se and Zn were set as 188.979, 233.527, 226.502, 267.716, 324.752, 259.939, 259.327, 231.604, 220.353, 196.022 , and $213.857 \mathrm{~nm}$ respectively, and the detection limits of the analyzed elements were As:0.006, Ba:0.002, Cd:0.001, Cr:0.001, Cu:0.002, Fe:0.002, Mn:0.002, Ni:0.001, Pb:0.005, Se:0.023, and Zn:0.001 mg/L. Analyses of blanks and standards were conducted for every 10th sample. The concentrations of the potentially toxic elements in the procedural blanks were significantly less than $5 \%$ of the mean analyzed concentrations for all potentially toxic elements. Replications of the analyses were conducted to guarantee the precision and accuracy of all measurements. The results were not found to deviate by more than $2 \%$ from the certified levels. The potentially toxic element recovery values were then calculated through acceptance in the range of $85-115 \%$. The values considered accurate were $90-100 \%[18,19]$.

\subsection{Chromosome Preparation and Assessment}

H. macrolepidota were injected with colchicine at $0.05 \% v / w$ and left for $1 \mathrm{~h}$. Then, the kidney was cut into small pieces, mixed with $8 \mathrm{~mL}$ of $0.075 \mathrm{M} \mathrm{KCl}$ (ACS grade) for $25 \mathrm{~min}$ and centrifuged at $1500 \mathrm{rpm}$ for $10 \mathrm{~min}$. The kidney cells were then fixed in a cool fixative ( 3 methanol:1 glacial acetic acid). The fixative was gradually added up to $8 \mathrm{~mL}$ before centrifugation at $1500 \mathrm{rpm}$ for $10 \mathrm{~min}$. The fixation process was repeated as the supernatant was cleared. The sediment was mixed with $1 \mathrm{~mL}$ of fixative, and the cell suspension was dropped on a glass slide. The air-dried slide was stained with a $20 \%$ Giemsa's solution for $30 \mathrm{~min}[20,21]$. A total of 500 metaphase chromosomes were photographed, counted and recorded under a light microscope at a magnification of $1000 \times$. The total number of chromosome abnormalities, total number of cells with chromosome abnormalities and the percentage of chromosome abnormalities were calculated and analyzed statistically. 


\subsection{Serum Liver Enzymes}

Clotted blood samples from the $H$. macrolepidota caudal vessel were centrifuged at $2000 \mathrm{rpm}$ for $10 \mathrm{~min}$, and the fish serum was stored at $-20^{\circ} \mathrm{C}$ before liver enzyme determination [22]. Serum enzymes aspartate aminotransferase (AST) and alanine aminotransferase (ALT) were measured using an automated analyzer (ROCHE/Hitachi Cobas C501, ROCHE/Hitachi, Roche Diagnostics K.K., Tokyo, Japan).

\subsection{Liver Histopathology Study}

H. macrolepidota livers were fixed in $1 \%$ osmium tetroxide (ACS grade) for 1 day, dehydrated in a series of ethyl alcohols (ACS grade), transferred to propylene oxide (ACS grade), and embedded in capsules with an Eppon polymer. Sections cut ultrathin sections using an ultramicrotome were stained with uranyl acetate and lead citrate (ACS grade) and observed under a transmission electron microscope (JEOL 100, JEOL Ltd., Tokyo, Japan) [23].

\subsection{Statistical Analysis}

The potentially toxic element concentrations in contaminated water, sediment, and fish muscles as well as liver enzymes were tested with independent $t$-tests comparing the differences between two unrelated areas. Water quality parameters, the total number of chromosome abnormalities, the cell numbers with chromosome abnormalities and the percentage of chromosome abnormalities in each fish near the Sepon gold-copper mine and the control areas were compared and analyzed statistically as independent observations using a Mann-Whitney U-test comparing between two independent areas without normal distribution, with SPSS program version 24 , at a $95 \%$ confidence level. Histological changes in fish liver cells were descriptively reported.

\section{Results}

\subsection{Parameters of Water Quality}

The values of the water quality parameters of water samples from the Nam Kok River near the gold-copper mine (as the study area) and the Nam Souang River (as the control area) are shown in Table 2.

Table 2. Water quality parameters in the Nam Kok River near the gold-copper mine (as the study area), and the Nam Souang River (as the control area).

\begin{tabular}{cccc}
\hline \multirow{2}{*}{ Samples } & \multicolumn{2}{c}{ Concentrations } & \\
\cline { 2 - 3 } & $\begin{array}{c}\text { Nam Kok River } \\
\text { (Study Area) }\end{array}$ & $\begin{array}{c}\text { Nam Souang River } \\
\text { (Control Area) }\end{array}$ & \\
\hline Temperature $\left({ }^{\circ} \mathrm{C}\right)$ & $23.65 \pm 0.46$ & $26.20 \pm 0.67$ & $0.009 *$ \\
$\mathrm{DO}(\mathrm{mg} / \mathrm{L})$ & $12.69 \pm 0.77$ & $7.96 \pm 0.57$ & $0.009^{*}$ \\
$\mathrm{pH}$ & $8.08 \pm 0.21$ & $7.65 \pm 0.34$ & $0.007^{*}$ \\
$\mathrm{TH}(\mathrm{mg} / \mathrm{L})$ & $114.00 \pm 5.48$ & $94.00 \pm 4.35$ & 0.215 \\
$\mathrm{CH}(\mathrm{mg} / \mathrm{L})$ & $11.00 \pm 5.48$ & $3.77 \pm 0.48$ & 0.154 \\
Nitrite $(\mathrm{mg} / \mathrm{L})$ & $0.03 \pm 0.02$ & $0.05 \pm 0.02$ & 0.118 \\
Nitrate $(\mathrm{mg} / \mathrm{L})$ & $7.43 \pm 1.85$ & $8.83 \pm 3.67$ & 0.062 \\
Ammonia $(\mathrm{mg} / \mathrm{L})$ & $0.02 \pm 0.001$ & $0.10 \pm 0.01$ & 0.065 \\
EC $(\mu \mathrm{s} / \mathrm{cm})$ & $443.40 \pm 12.67$ & $251.13 \pm 6.24$ & 0.207 \\
\hline
\end{tabular}

* Pooled standard error of statistically significant difference $(p<0.05)$. Remarks: dissolved oxygen (DO), potential of hydrogen $(\mathrm{pH})$, total hardness $(\mathrm{TH})$, carbonate hardness $(\mathrm{CH})$ and electrical conductivity (EC); (mean and standard deviation; $\mathrm{n}=3$ ).

\subsection{Potentially Toxic Element Concentrations in Water Samples}

The average potentially toxic element concentrations in the water samples as $\mathrm{mg} / \mathrm{L}$ are shown in Table 3. There were significant differences $(p<0.05)$ in the concentrations of all metals between the study and control areas. The average potentially toxic element concentrations of $\mathrm{Cd}, \mathrm{Cr}, \mathrm{Fe}, \mathrm{Mn}$ and $\mathrm{Pb}$ in the water samples in the study and control areas were 
$0.002 \pm 0.001$ and $0.001 \pm 0.001 \mathrm{mg} / \mathrm{L} ; 0.017 \pm 0.007$ and $0.018 \pm 0.015 \mathrm{mg} / \mathrm{L} ; 0.638 \pm 0.126$ and $0.910 \pm 0.265 \mathrm{mg} / \mathrm{L} ; 0.109 \pm 0.039$ and $0.112 \pm 0.016 \mathrm{mg} / \mathrm{L}$; and $0.038 \pm 0.030$ and $0.023 \pm 0.019 \mathrm{mg} / \mathrm{L}$, respectively. The results suggested that there were no significant differences $(p>0.05)$ in element concentrations other than for the $\mathrm{As}, \mathrm{Ba}, \mathrm{Cu}, \mathrm{Ni}$, Se and $\mathrm{Zn}$ in the water samples in both areas. The $\mathrm{Cu}$ and Se concentrations did not have reported standard values (Table 3 ).

Table 3. Potentially toxic element concentrations in water samples $(n=9)$ of the Nam Kok River near the gold-copper mine (as the study area) and the Nam Souang River (as the control area).

\begin{tabular}{|c|c|c|c|c|}
\hline \multirow{2}{*}{$\begin{array}{l}\text { Potentially Toxic } \\
\text { Elements }\end{array}$} & \multicolumn{2}{|c|}{ Concentration in Water (mg/L) } & \multirow[b]{2}{*}{$p$-Value } & \multirow[b]{2}{*}{ Standard } \\
\hline & $\begin{array}{l}\text { Nam Kok River } \\
\text { (Study Area) }\end{array}$ & $\begin{array}{l}\text { Nam Souang River } \\
\text { (Control Area) }\end{array}$ & & \\
\hline As & $0.005 \pm 0.002$ & $0.001 \pm 0.000$ & $0.008 *$ & $0.01^{\mathrm{a}}$ \\
\hline $\mathrm{Ba}$ & $5.581 \pm 0.774$ & $1.918 \pm 1.281$ & $0.009 *$ & $0.05^{\mathrm{g}}$ \\
\hline $\mathrm{Cd}$ & $0.002 \pm 0.001$ & $0.001 \pm 0.001$ & 0.142 & $0.01^{\mathrm{b}}$ \\
\hline $\mathrm{Cr}$ & $0.017 \pm 0.007$ & $0.018 \pm 0.015$ & 0.465 & $0.05^{\mathrm{d}}$ \\
\hline $\mathrm{Cu}$ & $0.031 \pm 0.006$ & $0.010 \pm 0.005$ & $0.009 *$ & - \\
\hline $\mathrm{Fe}$ & $0.638 \pm 0.126^{* *}$ & $0.910 \pm 0.265^{* *}$ & 0.076 & $0.30^{\mathrm{e}}$ \\
\hline $\mathrm{Mn}$ & $0.109 \pm 0.039 * *$ & $0.112 \pm 0.016^{* *}$ & 0.347 & $0.05^{\mathrm{f}}$ \\
\hline $\mathrm{Ni}$ & $0.351 \pm 0.436^{* *}$ & $0.017 \pm 0.009$ & $0.009 *$ & $0.02^{\mathrm{d}}$ \\
\hline $\mathrm{Pb}$ & $0.038 \pm 0.030$ & $0.023 \pm 0.019$ & 0.347 & $0.05^{b}$ \\
\hline Se & $0.007 \pm 0.002$ & $0.003 \pm 0.003$ & 0.047 * & - \\
\hline $\mathrm{Zn}$ & $3.526 \pm 0.615^{* *}$ & $1.797 \pm 0.978^{* *}$ & $0.028 *$ & $0.20^{\mathrm{c}}$ \\
\hline
\end{tabular}

* Pooled standard error ( $p$-value) of statistically significant difference $(p<0.05) ;{ }^{* *}$ Potentially toxic element concentration higher than standard reference value; Water standard references: ${ }^{a}$ [24], ${ }^{\mathrm{b}}$ [25], ' $[26],{ }^{\mathrm{d}}$ [27], e [28], ${ }^{\mathrm{f}}[29], \mathrm{g}$ [30].

\subsection{Potentially Toxic Element Concentrations in Sediment Samples}

The average potentially toxic element concentrations in sediment samples are shown as $\mathrm{mg} / \mathrm{kg}$ in Table 4 . The statistical results suggested that there were significant differences in all the studied potentially toxic element concentrations in sediment samples between the study area and the control area $(p<0.05)$. The concentrations of Ba, Fe and Se did not have reported standard values, and the concentration of Se in sediment in the Nam Kok area was not detected.

Table 4. Potentially toxic element concentrations in sediment samples ( $n=9)$ from the Nam Kok River near the gold-copper mine (as the study area) and the Nam Souang River (as the control area).

\begin{tabular}{|c|c|c|c|c|}
\hline \multirow{2}{*}{$\begin{array}{l}\text { Potentially Toxic } \\
\text { Elements }\end{array}$} & \multicolumn{2}{|c|}{ Concentration in Sediment (mg/kg) } & \multirow[b]{2}{*}{$p$-Value } & \multirow[b]{2}{*}{ Standard } \\
\hline & $\begin{array}{l}\text { Nam Kok River } \\
\text { (Study Area) }\end{array}$ & $\begin{array}{l}\text { Nam Souang River } \\
\text { (Control Area) }\end{array}$ & & \\
\hline As & $14.05 \pm 7.30$ ** & $0.03 \pm 0.02$ & $0.009 *$ & $3.90^{\mathrm{a}}$ \\
\hline $\mathrm{Ba}$ & $429.59 \pm 15.58$ & $12.42 \pm 16.07$ & $0.009 *$ & - \\
\hline $\mathrm{Cd}$ & $2.35 \pm 0.49^{* *}$ & $0.073 \pm 0.06$ & $0.009 *$ & $0.16^{\mathrm{b}}$ \\
\hline $\mathrm{Cr}$ & $18.08 \pm 5.96$ & $0.48 \pm 0.22$ & $0.009 *$ & $45.50^{b}$ \\
\hline $\mathrm{Cu}$ & $47.89 \pm 16.55^{* *}$ & $0.42 \pm 0.28$ & $0.009 *$ & $21.50^{b}$ \\
\hline $\mathrm{Fe}$ & $13,198.38 \pm 1861.08$ & $214.94 \pm 59.49$ & $0.000 *$ & - \\
\hline $\mathrm{Mn}$ & $231.97 \pm 95.91$ & $2.95 \pm 1.06$ & $0.009 *$ & $1800^{\mathrm{a}}$ \\
\hline $\mathrm{Ni}$ & $37.25 \pm 8.06$ & $1.89 \pm 1.79$ & $0.009 *$ & $75.00^{c}$ \\
\hline $\mathrm{Pb}$ & $50.50 \pm 14.73$ & $1.44 \pm 0.93$ & $0.009 *$ & $300.00^{c}$ \\
\hline Se & ND & $0.03 \pm 0.03$ & - & - \\
\hline $\mathrm{Zn}$ & $343.45 \pm 28.46^{* *}$ & $9.63 \pm 8.23$ & 0.009 * & $300.00^{c}$ \\
\hline
\end{tabular}

* Pooled standard error ( $p$-value) of statistically significant difference $(p<0.05)$; ${ }^{* *}$ Potentially toxic element concentration higher than standard reference value; sediment standard references: ${ }^{\mathrm{a}}[31], \mathrm{b}$ [32], ${ }^{\mathrm{c}}$ [33]. 


\subsection{Potentially Toxic Element Concentrations in H. macrolepidota Samples}

The average concentrations of potentially toxic elements in fish muscles as $\mathrm{mg} / \mathrm{kg}$ from the Nam Kok River near the gold-copper mine (as the study area) and the Nam Souang River (as the control area) are shown in Table 5. Potentially toxic element concentrations accumulated in the fish muscles from both studied areas were statistically significant $(p<0.05)$, whereas the concentrations of Fe in fish muscles from both areas, $44.74 \pm 19.21$ and $39.33 \pm 8.84 \mathrm{mg} / \mathrm{kg}$, respectively, were not significantly different $(p>0.05)$. The concentrations of $\mathrm{Ba}, \mathrm{Fe}, \mathrm{Ni}$, Se and $\mathrm{Zn}$ did not have reported standard values, and the concentration of $\mathrm{Pb}$ in the Nam Kok area was not detected (Table 5).

Table 5. Potentially toxic element concentrations in H. macrolepidota samples $(n=9)$ from the Nam Kok River near the gold-copper mine (as the study area) and the Nam Souang River (as the control area).

\begin{tabular}{|c|c|c|c|c|}
\hline \multirow{2}{*}{$\begin{array}{l}\text { Potentially Toxic } \\
\text { Elements }\end{array}$} & \multicolumn{2}{|c|}{ Concentration (mg/kg) } & \multirow[b]{2}{*}{$p$-Value } & \multirow[b]{2}{*}{ Standard } \\
\hline & $\begin{array}{l}\text { Nam Kok River } \\
\text { (Study Area) }\end{array}$ & $\begin{array}{l}\text { Nam Souang River } \\
\text { (Control Area) }\end{array}$ & & \\
\hline As & $0.30 \pm 0.10$ & $0.17 \pm 0.04$ & $0.047 *$ & $2.00^{\mathrm{a}}$ \\
\hline $\mathrm{Ba}$ & $0.89 \pm 0.41$ & $1.96 \pm 0.52$ & $0.016^{*}$ & - \\
\hline $\mathrm{Cd}$ & $0.21 \pm 0.09^{* *}$ & $0.02 \pm 0.001$ & 0.009 * & $0.05^{b}$ \\
\hline $\mathrm{Cr}$ & $3.58 \pm 0.54^{* *}$ & $1.67 \pm 0.23$ & 0.009 * & $2.00^{\mathrm{c}}$ \\
\hline $\mathrm{Cu}$ & $2.20 \pm 1.08$ & $1.32 \pm 0.22$ & $0.028 *$ & $10.00^{c}$ \\
\hline $\mathrm{Fe}$ & $44.74 \pm 19.21$ & $39.33 \pm 8.84$ & 0.917 & - \\
\hline $\mathrm{Mn}$ & $4.19 \pm 0.81^{* *}$ & $2.14 \pm 0.55^{* *}$ & 0.009 * & $1.00^{\mathrm{c}}$ \\
\hline $\mathrm{Ni}$ & $1.70 \pm 0.24$ & $0.97 \pm 0.11$ & 0.009 * & - \\
\hline $\mathrm{Pb}$ & ND & $0.04 \pm 0.04$ & - & $0.20^{\mathrm{d}}$ \\
\hline Se & $1.21 \pm 0.76$ & $0.28 \pm 0.08$ & 0.009 * & - \\
\hline $\mathrm{Zn}$ & $79.25 \pm 2.86$ & $62.22 \pm 15.95$ & 0.047 * & - \\
\hline
\end{tabular}

* Pooled standard error ( $p$-value) of statistically significant difference $(p<0.05)$; ${ }^{* *}$ Potentially toxic element concentration higher than standard reference value; Standard references: ${ }^{a}[34],{ }^{b}$ [35], ${ }^{c}[36],{ }^{d}$ [37].

\subsection{Chromosome Sssessment in H. macrolepidota}

The diploid chromosome number (2n) of H. macrolepidota from the study and the control areas was $2 \mathrm{n}=50$. The normal karyotype of $H$. macrolepidota from both areas consisted of 3 pairs of metacentric, 9 pairs of submetacentric, 6 pairs of acrocentric, and 7 pairs of telocentric regions (Figure 2). Figure 3 shows the different types of chromosome abnormalities in the metaphase spread cells. The results revealed that the 6 types of chromosome abnormalities in $H$. macrolepidota from the gold mining area were centric gaps, fragmentations, single chromatid gaps, deletions, single chromatid breaks and centric fragmentations, with a total number of chromosomal abnormalities being 127, 3, 3, 22, 1 , and 15, respectively. The total number of chromosome abnormalities, cell numbers with chromosome abnormalities and the percentage of chromosome abnormalities of H. macrolepidota in the study and the control areas were 171,73 and $29.20 \%$ and 39,27 and $10.80 \%$, respectively. The statistical results indicated that the total number of chromosome abnormalities, the total cell numbers with chromosome abnormalities and the percentages of chromosome abnormalities from both areas were significantly different $(p<0.05)$ (Table 6). 


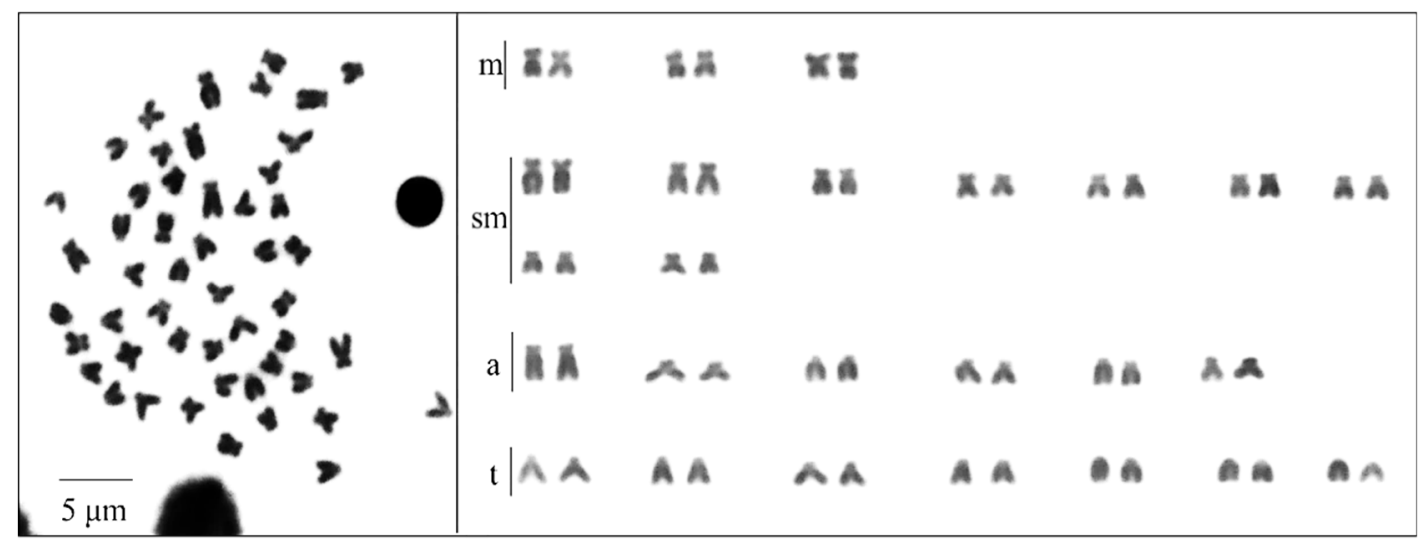

Figure 2. Karyotype of normal chromosome of H. macrolepidota $(2 \mathrm{n}=50)$; metacentric $(\mathrm{m})$, small metacentric $(\mathrm{sm})$, acrocentric (a) and telocentric (t).

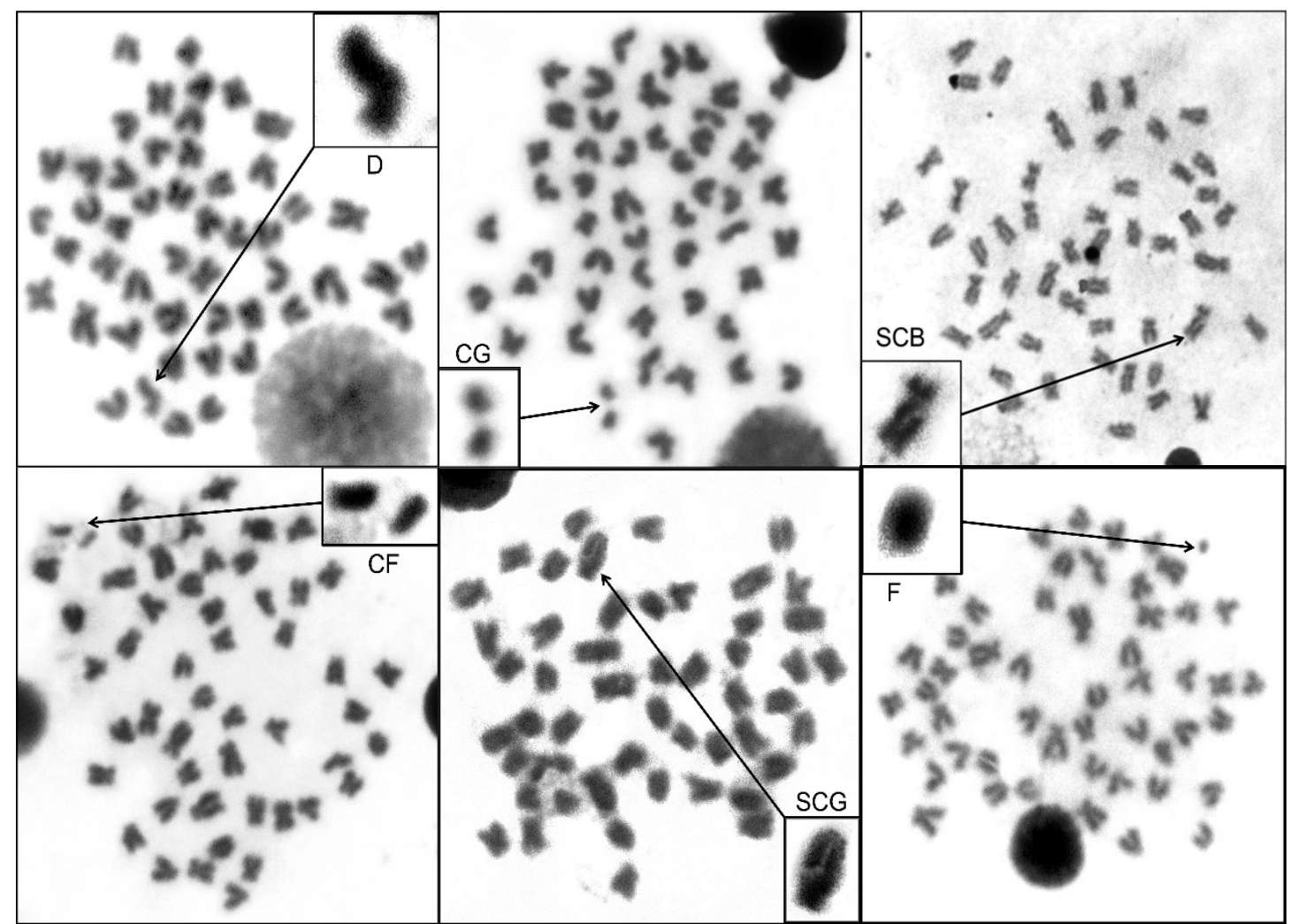

Figure 3. Six types of chromosome abnormalities in the metaphase spread cells of $H$. macrolepidota $(2 \mathrm{n}=50)$; deletion (D), centromere gap (CG), single chromatid break (SCB), centric fermentation (CF), single chromatid gap (SCG) and fragmentation $(\mathrm{F})$. 


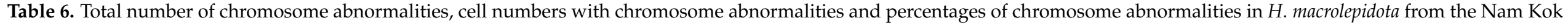
River near the gold-copper mine (as the study area) and the Nam Souang River (as the control area) (median interquartile range, $\mathrm{n}=9$ ).

\begin{tabular}{|c|c|c|c|c|c|c|c|c|c|}
\hline \multirow{2}{*}{ H. macrolepidota } & \multicolumn{6}{|c|}{ Number of Chromosome Abnormalities } & \multirow{2}{*}{ Total Number of CA } & \multirow{2}{*}{ Cell Number with CA } & \multirow{2}{*}{ Percentage of CA } \\
\hline & $\mathbf{F}$ & SCG & CG & $\mathbf{D}$ & SCB & $\mathrm{CF}$ & & & \\
\hline Study area & $0(1.5)$ & $0(1.5)$ & $21(20)$ & $5(2.5)$ & $0(0.5)$ & $2(2.5)$ & $30(19.5)$ & $15(4)$ & $30(8)$ \\
\hline Total/Average * & 3 & 3 & 127 & 22 & 1 & 15 & 171 & 73 & $29.20 *$ \\
\hline Control area & $0(0)$ & $0(0)$ & $6(2)$ & $1(0.5)$ & $0(0)$ & $0(1)$ & $8(2.5)$ & $6(3.5)$ & $12(7)$ \\
\hline Total/Average * & 0 & 0 & 30 & 6 & 0 & 3 & 39 & 27 & 10.80 * \\
\hline$p$-value & & & & & & & $0.009 * *$ & $0.009^{* *}$ & $0.009^{* *}$ \\
\hline
\end{tabular}

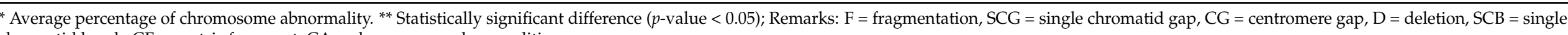
chromatid break, $\mathrm{CF}=$ centric fragment, $\mathrm{CA}=$ chromosome abnormalities. 


\subsection{Serum Liver Enzymes}

The liver enzymes (AST and ALT) of the fish from the study area near the gold-copper mine were higher and significantly different from those of the fish in the control area $(p<0.05)$ (Table 7).

Table 7. Serum liver enzyme parameters of $H$. macrolepidota.

\begin{tabular}{ccc}
\hline Parameter & $\begin{array}{c}\text { Nam Kok River } \\
\text { (Study Area) }(\mathbf{n}=\mathbf{9})\end{array}$ & $\begin{array}{c}\text { Nam Souang River } \\
\text { (Control Area) }(\mathbf{n}=\mathbf{9})\end{array}$ \\
\hline AST (IU/L) & $66.34 \pm 13.67 *$ & $32.67 \pm 4.34^{*}$ \\
ALT (IU/L) & $63.38 \pm 7.73^{*}$ & $28.67 \pm 2.27^{*}$ \\
\hline
\end{tabular}

* Significantly different in the same row $(p<0.05)$; Remarks: Aspartate aminotransferase (AST), Alanine aminotransferase (ALT).

\subsection{Liver Histopathology}

The liver cells of the control H. macrolepidota fish showed normal structures, such as (1) oval nuclei with condensed nucleoli, (2) cell membranes that were smooth without broken boundaries, (3) rough endoplasmic reticulum arranged in parallel and (4) normal-sized mitochondria (Figure 4a). In contrast, abnormal liver cells of the fish exposed to toxic elements showed (1) irregularly-shaped nuclei with scattered and lighter-colored nucleoli, (2) nuclear membrane breakage, (3) rough endoplasmic reticulum disintegration and (4) swollen and lighter-colored mitochondria (Figure 4 b).
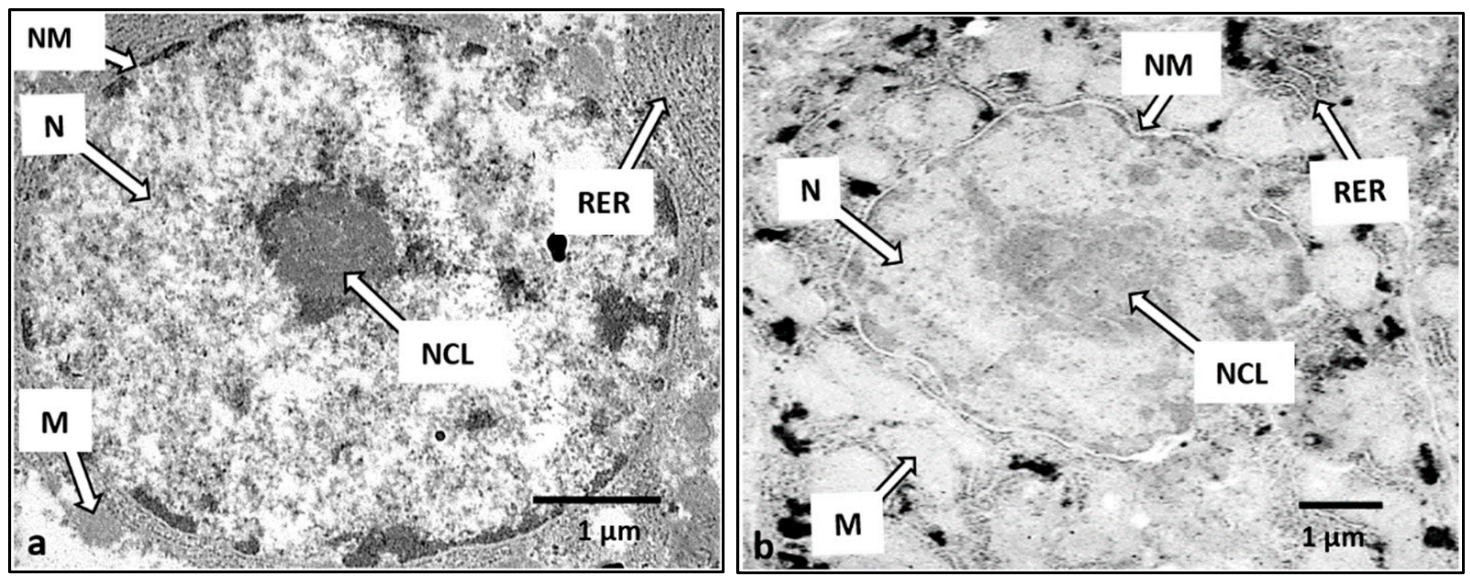

Figure 4. Electron micrograph of an H. macrolepidota liver cell. Nucleus (N), Nucleolus (NCL), Nuclear membrane (NM), Mitochondria (M), Rough endoplasmic reticulum (RER), Bar = $1 \mu \mathrm{m}$. Normal cell (a); Abnormal cell (b).

\section{Discussion}

\subsection{Water Quality Parameters}

Most of the measurements of water quality parameters were within the standards for non-contaminated surface water [38], especially dissolved oxygen (DO), temperature, the potential of hydrogen $(\mathrm{pH})$ and electrical conductivity (EC), and indicated that the water quality profile of the control area could be appropriate for fish to live, as recorded by Boyd [39]; Pruszynski [40]; Tram et al. [41]; Akinwole et al. [42]; Culioli et al. [43]; and Nguyen [44].

\subsection{Potentially Toxic Element Concentrations in Water, Sediment and H. macrolepidota}

The concentrations of $\mathrm{As}, \mathrm{Ba}, \mathrm{Cu}, \mathrm{Ni}$, Se and $\mathrm{Zn}$ in the water samples from the Nam Kok River near the gold-copper mine area and the control area were significantly different $(p<0.05)$, whereas the concentrations of $\mathrm{Cd}, \mathrm{Cr}, \mathrm{Fe}, \mathrm{Mn}$ and $\mathrm{Pb}$ in the water from both of the studied areas were not significantly different $(p>0.05)$. However, the concentrations of Fe, $\mathrm{Mn}, \mathrm{Ni}$ and $\mathrm{Zn}$ in the water from the Nam Kok River exceeded the water standards limit 
according to the FAO [26], FAO/WHO [27], US-EPA [28] and UNEPGEMS [29] notifications, as shown in Table 3. Furthermore, the Nam Souang River, as the control area, contains potentially toxic elements from agriculture and domestic activities, but does not exceed the water standards limit, except for Fe, Mn and $\mathrm{Zn}$. This could imply that the studied river was naturally enriched with some elements in the collected water.

These results are in accordance with other studies. Intamat et al. [45] and Khamlerd et al. [46] reported that the concentrations of $\mathrm{As}, \mathrm{Cr}, \mathrm{Fe}, \mathrm{Mn}$, and $\mathrm{Zn}$ in water around the gold mining area of Loei Province and the Bueng Jode reservoir near an industrial area in Thailand were higher than the standard values. Additionally, the concentrations of As, $\mathrm{Cd}$ and $\mathrm{Mn}$ from other gold mines, lakes, reservoirs and domestic wastewater canals in Thailand were greater than the standard values and non-contaminated areas [16,46-49].

Most of the potentially toxic element concentrations in the sediment from both studied areas suggested that they were significantly different $(p<0.05)$. The average concentrations of $\mathrm{As}, \mathrm{Cd}, \mathrm{Cu}$ and $\mathrm{Zn}$ in the sediment samples of the Nam Kok River were greater than the standard values according to the standards of TPCD [31], TPCD [32] and the EU [33], while the concentrations of $\mathrm{Cr}, \mathrm{Ni}, \mathrm{Mn}$ and $\mathrm{Pb}$ in the sediment were lower than the standard values. When compared, the concentrations of potentially toxic elements $\mathrm{As}$ and $\mathrm{Cd}$ in the sediment of the Nam Kok River near the gold-copper-mine area were higher than those of other research studies

Intamat et al. [45] and Tengjaroenkul et al. [17] determined that As and Cd were the two most prevalent elements in the sediment around the gold mine area of Loei Province, Thailand, and that the concentrations of $\mathrm{As}, \mathrm{Cd}, \mathrm{Cu}, \mathrm{Cr}, \mathrm{Pb}, \mathrm{Ni}, \mathrm{Fe}, \mathrm{Zn}$ and $\mathrm{Mn}$ reported in the Nam Kok River in this study were lower than those of other studies [45,46,50].

The average potentially toxic element concentrations in the muscle of $H$. macrolepidota are shown in Table 5. In addition to $\mathrm{Pb}$, ten potentially toxic element concentrations in the fish muscle samples from the study and the control areas were statistically significantly different $(p<0.05)$. The concentrations of $\mathrm{Cr}, \mathrm{Cd}$ and $\mathrm{Mn}$ in $\mathrm{H}$. macrolepidota muscles in the study area exceeded the standard values for freshwater fish $[35,36]$. As a carnivorous fish, $H$. macrolepidota can absorb potentially toxic elements into its body after feeding on contaminated elements via the digestive tract, which are directly distributed from toxic element-contaminated aquatic ecosystems into H. macrolepidota gills and skin. From previous studies on the Nam Kok River, potentially toxic element accumulations were found to differ among fish species. Soulivongsa et al. [15] reported that bony lip barb fish (Osteochilus vittatus) contained $\mathrm{As}, \mathrm{Cr}, \mathrm{Fe}, \mathrm{Mn}$ and $\mathrm{Ni}$ at greater concentrations than hampala barb fish in this study, with values of $3.48>0.30,4.72>3.58,56.10>44.74,14.76>4.19$ and $1.76>1.70 \mathrm{mg} / \mathrm{kg}$, respectively. These differences suggested that bony lip barb fish, an herbivorous fish, may consume an abundance of contaminated aquatic plants in the river in greater amounts. Therefore, higher accumulated concentrations were observed at a greater level. Furthermore, Jiang et al. [49] found that potentially toxic elements in the muscles of Cyprinus carpio and C. auratus from Lake Caizi in Southeast China had higher concentrations than the levels near the gold-copper mine area in this study. Keshavarzi et al. [51] performed health risk assessments in three fish species (Anodontostoma chacunda, Johnius belangerii and Cynogloddurs arel) in the Persian Gulf in Iran and found that the concentrations of As and Cd were higher than those of the metals in the H. macrolepidota muscle samples in this study. Furthermore, Neeratanaphan et al. [52] determined that the concentration of As in the Monopterus albus muscle and the concentrations of $\mathrm{Cd}, \mathrm{Cr}$, $\mathrm{Cu}, \mathrm{Ni}$ and $\mathrm{Zn}$ in Oreochromis niloticus muscle [50] were greater than the metal levels in this study, and Keshavarzi et al. [51] detected As and Cd in Anodontostoma chacunda. Khamlerd et al. [46] reported the concentrations of $\mathrm{Cr}, \mathrm{Cd}$, As, and $\mathrm{Ni}$ in Chana stariata at Bueng Jode reservoir, Khon Kaen province in Thailand, and Intamat et al. [45] found As, $\mathrm{Cr}, \mathrm{Cd}, \mathrm{Ni}, \mathrm{Fe}$ and $\mathrm{Mn}$ in the muscles of Rasbora tornieri around the gold mine area of Loei province, Thailand. 


\subsection{Chromosome Study in H. macrolepidota}

The results of this study revealed six types of chromosome abnormalities. The statistical results revealed that the number of cells with chromosome abnormalities, the total number of chromosome abnormalities and the percentages of chromosome abnormalities were significantly different $(p<0.05)$ between the H. macrolepidota fish samples from the Nam Kok River near the gold-copper mine and those from the Nam Souang River. Furthermore, compared with bonylip barb fish (Osteochilus vittatus) at the same study site [15], $H$. macrolepidota fish demonstrated fewer chromosomal effects in terms of the number of cells with chromosome abnormalities, the total number of chromosome abnormalities, and the percentages of chromosome abnormalities. These results could suggest that differences in metal toxicity consequences are species dependent.

Generally, potentially toxic elements depend on the fish species, the time of exposure, the concentrations of toxicants, the organ of exposure and excretion from the organs of each organism. Some scientists have studied chromosome abnormalities in aquatic animals around gold mine areas, wastewater canals, electronic waste and in in vitro experiments. Phoonaploy et al. [53] found five types of chromosome abnormalities in snakehead fish in reservoirs near industrial areas. Khamlerd et al. [46] reported that Channa striata affected by heavy metals ( $\mathrm{As}, \mathrm{Pb}, \mathrm{Cd}, \mathrm{Cr}, \mathrm{Cu}, \mathrm{Fe}, \mathrm{Zn}, \mathrm{Mn}$ and $\mathrm{Ni}$ ) from the Bueng Jode reservoir in Thailand showed seven types of chromosome abnormalities. Sriuttha et al. [50] and Tengjaroenkul et al. [54] demonstrated six types and five types of chromosome abnormalities in O. niloticus in a domestic wastewater canal and in an in vitro experiment, respectively. Neeratanaphan et al. [16] conducted a cytotoxic assessment of Esomus metallicus from a gold mine area in the Wang Saphung district of Loei Province in Thailand and found six types of chromosome abnormalities. In addition, research on Monopterus albus exposed to potentially toxic element contamination near a gold mine area found seven types of chromosome abnormalities [52]. The above cytotoxicity phenomena after $\mathrm{Pb}, \mathrm{As}, \mathrm{Cd}$ and $\mathrm{Ni}$ exposure in aquatic animals has been explained by several researchers. $\mathrm{Pb}$ may involve several indirect toxic mechanisms, such as oxidative damage, mitogenesis, DNA damage and alterations in gene transcription [55], and As could alter mitotic and replication indices, induce single strand DNA breaks and apoptosis, and inhibit DNA repair [56,57]. Cd can cause ploidy changes, oxidized bases, deletions and point mutations [58-60], and $\mathrm{Ni}$ can intervene in calcium-dependent enzyme activities, genetic expression, cell proliferation and DNA methylation [61,62]. From the negative effects indicated above, this study suggests that the potentially toxic elements accumulated in fish species can cause a decline in the fish population near a gold mine area.

\subsection{Serum Biohemistry Study in H. macrolepidota}

Measurements of the ALT and AST levels are valuable in the diagnosis of hepatic malfunctions as fish-metal health effects as well as the status of aquatic ecosystems. In this study, the AST and ALT of the fish from the study area near the Sepon gold-copper mine were significantly higher than those of the fish in the control area $(p<0.05)$, suggesting the occurrence of hepatic injury or liver impairment, likely due to potentially toxic element accumulation in this organ of H. macrolepidota, as in other fish. Rao et al. [63] found an increase in the level of AST in the maternal tissue of $H$. fulvipes as a response to the stress induced by potentially toxic elements. Asgah et al. [64] reported increases in the AST and ALT levels after exposure to Cd in the Nile tilapia O. niloticus. Naga et al. [65] revealed significant potentially toxic element consequences on AST and ALT in marine fish Mugil seheli. Furthermore, potentially toxic elements can negatively affect fish health in terms of protein, carbohydrate and lipid profiles [66]. Furthermore, compared with bonylip barb fish (O. vittatus) at the same study site [15], H. macrolepidota fish demonstrated greater levels of both liver enzymes, particularly AST, which is directly related to the metal concentrations in the liver of H. macrolepidota fish. 


\subsection{Histopathology Study in H. macrolepidota}

The liver is a major organ involved in the accumulation and detoxification of toxic substances. Potentially toxic elements adversely affect the function of aquatic animal organs, causing changes in hepatic enzyme activities, extravasation of blood and necrosis of liver cells, fusion of gill lamellae, and genotoxicity [67-70]. Since the Nam kok River (as the study area located near the gold-copper mine) demonstrated higher levels of, and significantly different $(p<0.05)$, potentially toxic elements than the Nam Souang River (as a control area without mining activities), the abnormal liver cell structures in H. macrolepidota from the study clearly revealed pathological lesions, including nuclear membrane degeneration, rough endoplasmic reticulum disintegration and abnormal cytoplasmic mitochondria. These changes imply that the potentially toxic element concentrations in H. macrolepidota near the Sepon gold-copper mine could induce liver cell structural changes, as in the bonylip barb fish (O. vittatus) at the same study site [15]. The results were in accordance with several previous studies. Giari et al. [23] found mitochondrial and endoplasmic reticulum defects after exposure to $\mathrm{Cd}$, and Dyk et al. [71] found that $\mathrm{Cd}$ exposure could damage the liver cell structures of Oreochromis mossambicus. Mishra and Mohanty [72] revealed that the occurrence of degenerative nuclei could be induced by metal free radicals. Vinodhini and Narayanan [73] reported that accumulated potentially toxic elements could cause cellular degeneration in the liver of Cyprinus carpio.

\section{Conclusions}

The concentrations of $\mathrm{As}, \mathrm{Ba} \mathrm{Cd}, \mathrm{Cr}, \mathrm{Cu}, \mathrm{Fe}, \mathrm{Mn}, \mathrm{Ni}, \mathrm{Pb}$, Se and $\mathrm{Zn}$ in water, sediment, and fish samples in the Nam Souang River near the agriculture and domestic areas, naturally enriched with some elements, were lower than those from the Nam Kok River near the gold-copper mine. The potentially toxic element concentrations (As, Ba, $\mathrm{Cd}, \mathrm{Cr}, \mathrm{Cu}, \mathrm{Fe}, \mathrm{Mn}, \mathrm{Ni}, \mathrm{Zn}$ and $\mathrm{Pb}$ ) in the sediment were higher than those in the water samples, except for the undetected Se in the study area. Some potentially toxic element concentrations (Fe, Mn, Ni and $\mathrm{Zn}$ ) in water exceeded the FAO, USA and WHO standards, while some potentially toxic elements (As, $\mathrm{Cd}, \mathrm{Cu}$ and $\mathrm{Zn}$ ) in sediment exceeded the EU and Thailand standards. Furthermore, the average concentrations of $\mathrm{Cd}, \mathrm{Cr}$ and $\mathrm{Mn}$ in H. macrolepidota from the study area exceeded the food quality standards of the EC and WHO. The toxicities of potentially toxic elements in H. macrolepidota fish in the Nam Kok River near the Sepon gold-copper mine likely occurred due to their accumulation in fish cells, tissues, and organs, which can lead to abnormalities in chromosomes, changes in liver enzymes and alterations in the liver cell structures. The investigated information can apply to environmental and human health risk management and can contribute to the improvements of standards, regulations and policies regarding the mining industry in the Lao People's Democratic Republic.

Author Contributions: Conceptualization, L.N. and B.T.; methodology, L.S., B.T., I.P. and L.N.; software, L.S. and I.P.; validation, B.T. and L.N.; formal analysis, B.T., L.N., I.P. and L.S.; investigation, B.T., I.P., L.N. and L.S.; resources, L.N. and B.T.; writing-original draft preparation, B.T., L.N. and L.S.; writing-review and editing, B.T. and L.N.; supervision, B.T. and L.N.; project administration, B.T. and L.N.; funding acquisition, B.T. All authors have read and agreed to the published version of the manuscript.

Funding: This research was funded by Toxic Substances, Microorganisms and Feed Additives in Livestock and Aquatic Animals for Food Safety Research Program, Khon Kaen University, Khon Kaen 40002, Thailand.

Institutional Review Board Statement: The study was conducted according to the guidelines and approved by the Institution Animal Care and Use Committee of Khon Kaen University (IACUCKKU-1/63; Ref. No. 660201.2.11/1).

Informed Consent Statement: Informed consent was obtained from all subjects involved in the study. 
Data Availability Statement: The data presented in this study are available on request from the corresponding author.

Conflicts of Interest: The authors declare no conflict of interest.

\section{References}

1. World Bank. Lao PDR Investment Climate Assessment: Policies to Promote Growth in the Non-Resource Sectors; Report No 64800-LA; Poverty Reduction and Economic Management Sector Department, East Asia and Pacific Region, The International Bank for Reconstruction and Development/The World Bank: Vientiane, Laos, 2010.

2. Ngangnouvong, I. Mining in Laos, Economic Growth, and Price Fluctuation. In Proceedings of the United Nations Conference on Trade and Development, The 11th Multi-Year Expert Meeting on Commodities and Development, Geneva, Switzerland, 15-16 April 2019.

3. International Council on Mining and Metals (ICMM). Utilizing Mining and Mineral Resources to Foster the Sustainable Development of the Lao PDR; National Economic Research Institute (NERI), National University of Laos (NUOL): Vientiane, Laos, 2011.

4. Houngaloune, S.; Inthavongsa, I. Trends of Gold Mining Industry in Lao PDR. In Proceedings of the 13th International Conference on Mining, Materials and Petroleum Engineering (CMMP2019), Krabi, Thailand, 13-14 June 2019.

5. Phonvisay, S. An introduction to the Fisheries of Lao PDR; Mekong Development Series; Mekong River Commission: Phnom Penh, Cambodia, 2013; No. 6; ISSN 1680-4023.

6. Wells-Dang, A.; Soe, K.N.; Inthakoun, L.; Tola, P.; Socheat, P.; Van, T.T.; Chabada, A.; Youttananukorn, W. A political economy of environmental impact assessment in the Mekong region. Water Altern. 2016, 9, 33-55.

7. Global Green Growth Institute (GGGI). Green Growth Potential Assessment Lao PDR Country Report; Global Green Growth Institute: Seoul, Korea, 2017.

8. Chandanshive, N.E. The seasonal fluctuation of physico-chemical parameters of river Mula-Mutha at Pune, India and their impact of fish biodiversity. Res. J. Anim. Vet. Fish. Sci. 2013, 1, 11-16.

9. Govind, P.; Madhuri, S. Heavy metals causing toxicity in animals and fishes. Res. J. Anim. Vet. Fish. Sci. 2014, 2, 17-23.

10. Danita B'ey, T. Effects of Chronic, Sublethal Ferric Iron Exposure on the Critical Swim Speed of Rainbow Trout (Oncorhynchus mykiss) and Critical Thermal Maximum of Cutthroat Trout (Oncorhynchus clarkii). Master's Thesis, Colorado State University, Fort Collins, CO, USA, 2015.

11. Shibukawa, K.; Musikasinthorn, P.; Grudpan, C.; So, N.; Tran, D.; Praxaysombath, B. Fishes of the Indochinese Mekong; Nagao Natural Environment Foundation, Member from Cambodia, Lao PDR, Thailand and Vietnam, Nha Xuat BAN Dai CAN THO: Cantho City, Vietnam, 2012.

12. Shazili, N.A.M.; Yunus, K.; Ahmad, A.S.; Abdullah, N.; Rashid, M.K.A. Heavy metal pollution status in the Malaysian aquatic environment. Aquat. Ecosyst. Health Manag. 2006, 9, 137-145. [CrossRef]

13. Ünlü, S.; Topçuoğlu, S.; Alpar, B.; Kırbaşoğlu, Ç.; Yılmaz, Y.Z. Heavy metal pollution in surface sediment and mussel samples in the Gulf of Gemlik. Environ. Monit. Assess. 2008, 144, 169-178. [CrossRef] [PubMed]

14. Alloway, B.J. Heavy Metals in Soils: Trace Metals and Metalloids in Soils and Their Bioavailability, 3rd ed.; Springer: New York, NY, USA, 2013.

15. Soulivongsa, L.; Tengjaroenkul, B.; Neeratanaphan, L. Effects of contamination by heavy metals and metalloids on chromosomes, serum biochemistry and histopathology of the bonylip barb fish near Sepon gold-copper mine, Lao PDR. Int. J. Env. Res. Public Health 2020, 17, 9492. [CrossRef]

16. Neeratanaphan, L.; Khamlerd, C.; Chowrong, S.; Intamat, S.; Sriuttha, M.; Tengjaroenkul, B. Cytotoxic assessment of flying barb fish (Esomus metallicus) from a gold mine area with heavy metal contamination. Int. J. Environ. Stud. 2017, 74, 613-624. [CrossRef]

17. Tengjaroenkul, B.; Intamat, S.; Boonmee, S.; Neeratanaphan, L. Chromosomal aberration assessment of silver rasbora fish (Rasbora tornieri) living near gold mine area with heavy metal contamination. Hum. Ecol. Risk Assess. 2017, 23, 1140-1152. [CrossRef]

18. American Public Health Association (APHA). Standard Methods for the Examination of Water and Waste-Water; American Public Health Association: Washington, DC, USA; American Water Works Association: Denver, CO, USA; Water Environment Federation: Alexandria, VA, USA, 2012.

19. Chand, V.; Prasad, S. ICP-OES assessment of heavy metal contamination in tropical marine sediments: A comparative study of two digestion techniques. Microchem. J. 2013, 111, 53-61. [CrossRef]

20. Rooney, D.E. Human Cytogenetics Constitutional Analysis: A Practical Approach; Oxford University Press: London, UK, 2001.

21. Maneechot, N.; Supiwong, W.; Jumrusthanasan, S.; Siripiyasing, P.; Pinthong, K.; Tanomtong, A. Chromosomal characteristics of the royal knifefish, Chitala blanci (Osteoglossiformes, Notopteridae) by conventional and Ag-NOR staining techniques. Cytologia 2015, 80, 159-166. [CrossRef]

22. Reynders, H.; Campenhout, K.V.; Bervoets, L.; Coen, W.M.D.; Blust, R. Dynamics of cadmium accumulation and effects in common carp (Cyprinus carpio) during simultaneous exposure to water and food (Tubifex tubifex). Environ. Toxicol. Chem. 2006, 25, 1558-1567. [CrossRef] [PubMed]

23. Giari, L.; Manera, M.; Simoni, E.; Dezfuli, B.S. Cellular alterations in different organs of European sea bass Dicentrarchus labrax (L.) exposed to cadmium. Chemosphere 2007, 67, 1171-1181. [CrossRef]

24. World Health Organization (WHO). Arsenic in Drinking-Water. In Background Document for Preparation of WHO Guidelines for Drinking-Water Quality; World Health Organization: Geneva, Switzerland, 2011. 
25. Thailand Pollution Control Department (TPCD). Surface Water Quality Standard, Notification of the National Environmental Board, No. 8; Ministry of Natural Resource and Environment: Bangkok, Thailand, 1994.

26. Food and Agriculture Organization (FAO). Water Quality for Agriculture; FAO Irrigation and Drainage Paper 29, Rev. 1; Food and Agriculture Organization of the United Nations: Rome, Italy, 1994.

27. Food and Agriculture Organization; World Health Organization. National Research Council Recommended Dietary. In Allowances, 10th ed.; National Academy Press: Washington, DC, USA, 1989.

28. United States-Environmental Protection Agency (US-EPA). Water Quality Standard for Surface Water; US-EPA: Washington, DC, USA, 2002.

29. United Nations Environment Programme Global Environment Monitoring System (UNEPGEMS). Water Quality for Ecosystem and Human Health, 2nd ed.; United Nations Environment Programme Global Environment Monitoring System (GEMS)/Water Programme: Burlington, ON, Canada, 2008.

30. Awashthi, S.K. Prevention of Food Adulteration Act No. 37 of 1954; Central and State Rules as Amended for 1999; Ashoka Law House: New Delhi, India, 2000.

31. Thailand Pollution Control Department (TPCD). Soil Quality Standard for Residential and Agricultural Use According; Notification of the National Environment Board No. 25; Ministry of Natural Resource and Environment: Bangkok, Thailand, 2004.

32. Thailand Pollution Control Department (TPCD). Criteria for Sediment Quality Standard in Surface Water Source Net. No.2; Ministry of Natural Resource and Environment: Bangkok, Thailand, 2018.

33. European Union (EU). Heavy Metals in Wastes; European Commission on Environment: Copenhagen, Denmark, 2002.

34. Australia and New Zealand Standards. Contaminants and Natural Toxicants, Code-Standard 1.4.1; Federal Register of Legislative Instruments F2011C00542; Standards Australia: Canberra, Australia, 2011.

35. European Commission (EC). Commission Regulation (EC) No 78/2005 Amending Regulation (EC) No $466 / 2001$ as Regards Heavy Metals; L 16/43-45; Official Journal of the European Union: Luxembourg, 2005. Available online: https:/ / eur-lex.europa. eu/LexUriServ /LexUriServ.do?uri=OJ:L:2005:016:0043:0045:EN:PDF (accessed on 29 May 2021).

36. World Health Organization (WHO). Heavy Metals Environmental Aspects; Environment Health Criteria; World Health Organization: Geneva, Switzerland, 1989.

37. European Commission (EC). Commission Regulation (EC) No 466/2001 of 8 March 2001 Setting Maximum Levels for Certain Contaminants in Foodstuffs; European Comission: Luxembourg, 2001.

38. Thailand Pollution Control Department (TPCD). Water Quality Standards. Notification in Ministry of Public Health, No.98; Pollution Control Department: Bangkok, Thailand, 2001.

39. Boyd, C.E. Water Quality Management for Pond Fish Culture; Elsevier Scientific Publishing Co.: Amsterdam, The Netherlands, 1982.

40. Pruszynski, T. Effects of feeding on ammonium excretion and growth of the African catfish (Clarias gariepinus) fry. Czech J. Anim. Sci. 2003, 48, 106-112.

41. Tram, N.D.Q.; Ngoan, L.D.; Ogle, B. Effect of Processing Pig Manure through a Biodigester as Fertilizer for Fish Ponds on Water Quality and Growth Performance of Three Fish Species. Available online: https://www.researchgate.net/publication/242358467 (accessed on 26 August 2020).

42. Akinwole, A.O.; Faturoti, E.O. Biological performance of African catfish (Clarias gariepinus) cultured in recirculating system in Ibadan. Aquac. Eng. 2007, 36, 18-23. [CrossRef]

43. Culioli, J.L.; Calendini, S.; Mori, C.; Orsini, A. Arsenic accumulation in a freshwater fish living in a contaminated river of Corsica, France. Ecotoxicol. Environ. Saf. 2009, 72, 1440-1445. [CrossRef]

44. Nguyen; Nhi, H.Y. Utilization of Earthworms (Perionyx excavatus) as a Protein Source for Growing Fingerling Marble Baby (Oxyeleotris marmoratus) and Catfish (Pangasius hypophthalmusi). Master's Thesis, Swedish University of Agriculture Sciences, Uppsala, Sweden, 2010.

45. Intamat, S.; Phoonaploy, U.; Sriuttha, M.; Tengjaroenkul, B.; Neeratanaphan, L. Heavy metal accumulation in aquatic animals around the gold mine area of Loei province, Thailand. Hum. Ecol. Risk Assess. 2016, 22, 1418-1432. [CrossRef]

46. Khamlerd, C.; Tengjaroenkul, B.; Neeratanaphan, L. Abnormal chromosome assessment of snakehead fish (Channa striata) affected by heavy metals from a reservoir near an industrial factory. Int. J. Environ. Stud. 2019, 76, 648-662. [CrossRef]

47. Khammanichanh, A. Cytotoxic Assessment of Heavy Metal Concentration of Nile Tilapia (Oreochromis nioticus) from Domestic Wastewater Canal in Mung District of Maha Sarakham Province of Thailand. Master's Thesis, Khon Kaen University, Khon Kaen, Thailand, 2016.

48. Boonmee, S.; Thitiyan, T.; Tanomtong, A.; Tengjaroenkul, B.; Neeratanaphan, L. Cytotoxicity in the frog (Fejervarya limnocharis) after acute cadmium exposure in vivo. Int. J. Environ. Stud. 2018, 75, 978-989. [CrossRef]

49. Jiang, Z.; Xu, N.; Liu, B.; Zhou, L.; Wang, J.; Wanga, C.; Dai, B.; Xiong, W. Metal concentrations and risk assessment in water, sediment and economic fish species with various habitat preferences and trophic guilds from Lake Caizi, Southeast China. Ecotoxicol. Environ. Saf. 2018, 157, 1-8. [CrossRef]

50. Sriuttha, M.; Khammanichanh, A.; Patawang, I.; Tanomtong, A.; Tengjaroenkul, B.; Neeratanaphan, L. Cytotoxic sssessment of Nile tilapai (Oreochromis niloticus) from a domestic wastewater canal with heavy metal contamination. Cytologia 2017, 82, 41-50. [CrossRef] 
51. Keshavarzi, B.; Hassanaghaei, M.; Moore, F.; Mehr, M.R.; Soltanian, S.; Lahijanzadeh, A.R.; Sorooshian, A. Heavy metal contamination and health risk assessment in three commercial fish species in the Persian Gulf. Mar. Pollut. Bull. 2018, 129, 245-252. [CrossRef]

52. Neeratanaphan, L.; Kanjanakunti, A.; Intamat, S.; Tengjaroenkul, B. Analysis of chromosome abnormalities in the Asian swamp eel (Monopterus albus) affected by arsenic contamination near a gold mine area. Int. J. Environ. Stud. 2020, 77, 815-829. [CrossRef]

53. Phoonaploy, U.; Intamat, S.; Tengjaroenkul, B.; Sriuttha, M.; Tanamtong, A.; Neeratanaphan, L. Evaluation of abnormal chromosomes in rice field frogs (Fejervarya limnocharis) from reservoirs affected by leachate with cadmium, chromium and lead contamination. EnvironmentAsia 2016, 9, 26-38.

54. Tengjaroenkul, B.; Intamat, S.; Thanomsangad, P.; Phoonaploy, U.; Neeratanaphan, L. Cytotoxic effect of sodium arsenite on Nile tilapia (Oreochromis niloticus) in vivo. Int. J. Environ. Stud. 2018, 75, 580-591. [CrossRef]

55. Silbergeld, E.K. Facilitative mechanisms of lead as a carcinogen. Mutat. Res. Fundam. Mol. Mech. Mutagen. 2003, 533, 121-133. [CrossRef] [PubMed]

56. Sordo, M.; Herrera, L.A.; Wegman, P.O.; Rojas, E. Cytotoxic and genotoxic effects of As, MMA, and DMA on leukocytes and stimulated human lymphocytes. Teratog. Carcinog. Mutagen. 2001, 21, 249-260. [CrossRef] [PubMed]

57. Gomez, S.E.; Razo, L.M.D.; Sanchez, J.L.M. Induction of DNA damage by free radicals generated either by organic or inorganic arsenic (AsIII, MMAIII, and DMAIII) in cultures of B and T lymphocytes. Biol. Trace Elem. Res. 2005, 108, 115-126. [CrossRef]

58. Waalkes, M.P. Cadmium carcinogenesis. Mutat. Res. Fundam. Mol. Mech. Mutagen. 2003, 533, 107-120. [CrossRef]

59. Castano, A.; Becerril, C. In vitro assessment of DNA damage after short- and long-term exposure to benzo(a)pyrene using RAPD and the RTG-2 fish cell line. Mutat. Res. Fundam. Mol. Mech. Mutagen. 2004, 552, 141-151. [CrossRef]

60. Suhartono, E.; Yunanto, A.; Firdaus, R.T. Chronic cadmium hepatooxidative in rats: Treatment with haruan fish (Channa striata) extract. APCBEE Procedia 2013, 5, 441-445. [CrossRef]

61. Buschini, A.; Pinelli, S.; Pellacni, C.; Giordani, F.; Ferrari, M.B.; Bisceglie, F.; Giannetto, M.; Pelosi, M.; Tarasconi, P. Synthesis, characterization and deepening in the comprehension of the biological action mechanisms of a new nickel complex with antiproliferative activity. J. Inorg. Biochem. 2009, 103, 666-677. [CrossRef] [PubMed]

62. Zhou, X.; Li, Q.; Arita, A.; Sun, H.; Costa, M. Effects of nickel, chromate, and arsenite on histone 3 lysine methylation. Toxicol. Appl. Pharmacol. 2009, 236, 78-84. [CrossRef] [PubMed]

63. Rao, M.V.R.; Acharya, Y.; Naik, J.K.; Fatteh, S.; Fateh, A.S.; Pawar, A.C. Study of heavy metals in abnormal growth and development using an alternate animal model: Heterometrus fulvipes. Int. J. Life Sci. Sci. Res. 2017, 3, 1441-1450. [CrossRef]

64. Asgah, N.A.A.; Warith, A.W.A.A.; Younis, E.S.M.; Allam, H.Y. Haematological and biochemical parameters and tissue accumulations of cadmium in Oreochromis niloticus exposed to various concentrations of cadmium chloride. Saudi J. Biol. Sci. 2015, 22, 543-550. [CrossRef]

65. Naga, E.H.A.E.; Moselhy, K.M.E.; Hamed, M.A. Toxicity of cadmium and copper and their effect on some biochemical parameters of marine fish, Mugil sheheli. Egypt. J. Aquat. Res. 2005, 31, 60-71.

66. Javed, M.; Usmani, N. Stress response of biomolecules (carbohydrate, protein and lipid profiles) in fish Channa punctatus inhabiting river polluted by Thermal Power Plant effluent. Saudi J. Biol. Sci. 2015, 22, 237-242. [CrossRef] [PubMed]

67. Ahmed, K.; Ahmed, K.; Akhand, A.A.; Hasan, M.; Islam, M.; Hasan, A. Toxicity of arsenic (sodium arsenite) to fresh water spotted snakehead Channa punctatus (Bloch) on cellular death and DNA content. J. Agric. Environ. Sci. 2008, 4, 18-22.

68. Ahmed, M.K.; Mamun, M.H.A.; Hossain, M.A.; Parvin, M.A.E.; Akter, M.S.; Khan, M.S.; Islam, M.M. Assessing the genotoxic potentials of arsenic in tilapia (Oreochromis mossambicus) using alkaline comet assay and micronucleus test. Chemosphere 2011, 84, 143-149. [CrossRef]

69. Vera-Candioti, J.; Soloneski, S.; Larramendy, M.L. Acute toxicity of chromium on Cnesterodon decemmaculatus (pisces: Poeciliidae) (La toxicidad aguda del cromo en Cnesterodon decemmaculatus (pisces: Poeciliidae)). Theoria 2011, 20, 81-88.

70. Ahmed, M.K.; Mamun, M.H.A.; Parvin, E.; Akter, M.S.; Khan, M.S. Arsenic induced toxicity and histopathological changes in gill and liver tissue of freshwater fish, tilapia (Oreochromis mossambicus). Exp. Toxicol. Pathol. 2013, 65, 903-909. [CrossRef]

71. Dyk, J.C.; Pieterse, G.M.; Vuren, J.H.J. Histological changes in the liver of Oreochromis mossambicus (Cichlidae) after exposure to cadmium and zinc. Ecotoxicol. Environ. Saf. 2007, 66, 432-440. [PubMed]

72. Mishra, A.K.; Mohanty, B. Chronic exposure to sublethal hexavalent chromium affects organ histopathology and serum cortisol profile of a teleost, Channa punctatus (Bloch). Sci. Total Environ. 2009, 407, 5031-5038. [CrossRef] [PubMed]

73. Vinodhini, R.; Narayanan, M. Heavy metal induced histopathological alterations in selected organs of the Cyprinus carpio L. (Common Carp). Int. J. Environ. Res. 2009, 3, 95-100. 